\title{
The grand challenge of microbiology: to know better, protect, utilize and celebrate the unseen majority on our planet
}

\section{Martin G Klotz*}

University of Louisville, Louisville, KY, USA

*Correspondence: martin.klotz@frontiersin.org

Microorganisms (microbes) thrive everywhere on planet Earth as long as there are opportunities for exchanging Redox energy with the environment and for the harvest of nutrients including life's central element, carbon. The use of the term "Microbe" has changed with time and while it described at one point all living things not visible with the naked eye, the status quo of science today justifies its usage mainly to part "genetically programmed entities" from animals and plants. This would allow also the inclusion of viruses as they are such entities albeit not living organisms that can escape from host cells without losing their genetic program. We know now that their evolution is intimately connected to the evolution of cellular beings (Koonin, 2009 and references therein).

After Linneus, Haeckel, Cohn, OrlaJensen, Chatton, Whittaker, Stanier and Doudoroff, research by Carl Woese and colleagues beginning in the 1970s pioneered a new understanding of relationships between all cellular organisms (Woese and Fox, 1977; Woese et al., 1990), which provided a scientific basis for a natural classification of the "unseen majority of life" (Whitman et al., 1998; Ward, 2002; Heijden et al., 2008) and contributed greatly to our present understanding of the origin of life (Koonin and Martin, 2005; Russell, 2007; Wachtershauser, 2007; Forterre, 2008; Glansdorff et al., 2008; Lane et al., 2010). Much of this insight was possible from the realization that the becoming of Earth and life are intricately intertwined, that microbial life was the sole occupant for over half of Earth's existence and that microbial life is likely plentiful in the Universe. To tie all this together required new thinking in the "ligand sphere" (Wachtershauser, 1994; Martin and Russell, 2003) as well as a revolution in experimental methodology such as dideoxy-primer sequencing and PCR. Both methods were sparked by the brilliant concept of primer extension developed by Ray $\mathrm{Wu}$ (Wu, 1970; Wu and Taylor, 1971), whose applications provided later for molecular (microbial) ecology and the key to open the door to the $\sim$ omics age thereby paving the way for the present biodiversity initiative and hot new areas in the biological sciences such as Phylogenomics and Systems MicroBiology.

While phototrophy was conceptually easily accessible to scientists' and laypersons' thinking, the discovery of lithotrophy ("chemosynthesis") by the great Sergei Winogradsky $(1887,1890)$ still before the turn to the 20th century finally allowed for a biochemical and physiological explanation of light-less primary production, observed as a phenomenon over centuries by a large number ecologists and physiologists. Finally, Kluyver (1924) together with his colleague Hendrick Donker (Kluyver and Donker, 1926) proposed their far-reaching hypothesis on the unity (universality) of synthesis, then the trailblazer for Cornelius van Niel's concept of a "General Microbiology" and today one of the last standing paradigms in biology. Now, more than a century later, we know that microorganisms are "the greatest chemists" on our planet capable of exploiting every chemical reaction that is thermodynamically feasible to sustain themselves and proliferate, whether with or without light. This metabolic wizardry enabling the facilitation of global biogeochemical cycles - supported by large scale recycling via plate tectonics - is the basis of all life as we know it. It is currently estimated that the global microbial network consists of more than $10^{30}$ Bacteria and Archea, many of which are infected by a large cohort of the estimated total count of $10^{31}$ viruses. Add to it the estimate for the biodiversity of organisms in the Kingdom Fungi, of which only about $5 \%$ of the estimated 1.5 million species has been formally classified, and the plot is thickening.

Koch's (1876) first scientific implication of a bacterium as the causal agent of disease in an animal and Burrill's (1878) identification of a bacterium as the cause of plant disease were followed by numerous etiological reports that implicated bacteria (i.e., Kitasato, Klebs, Koch, Loeffler, Neisser, Pasteur, Pfeiffer, Roux, Smith and Kilbourne, Welch and Nuttall, and Yersin), parasites (Lewis, 1878), fungi (Ophuls and Moffitt, 1900) and viruses (Ivanowski, 1892; Reed et al., 1900) as the causal agents of disease, paired with research on how to protect healthy and infected hosts from (re)exposure, which also started the race for the cure (Pasteur, Ehrlich, Metchnikoff) and, eventually, research (Ehrlich, Kitasato, von Behring) that nurtured hope for finding a "silver bullet." This time was also the beginning of research that paved the way for the purposeful use of microbes to the benefit of mankind such as the souring of milk (Lister, 1878) in today's dairy industry and the use of nitrification (Schloesing and Muntz, 1877) for sewage treatment and bioremediation.

Like all of our science colleagues, microbiologists teach and train college students, interact with the lay public and their reflection on the field is a welcome feedback to not necessarily what we do and know but how we succeed in communicating it understandably to those who stand outside. It is often disheartening to hear how little interest all of microbiology but the work on causal agents of human disease (and their defeat) command. I usually escape the frustration by posing the following question: "Imagine that we found the therapies to cure all cancers and genetic failures and can combat every infectious disease directly or indirectly (i.e., by contaminated food) caused by bacteria, fungi, viruses and parasites. Do you think that would allow mankind to thrive and prosper?" I then answer the usually predictable "yes" response by the audience with the following challenge: "So what if we run out of potable water?" This usually ends in complete amazement ... and it is then when the crowd understands that planet Earth is maintained and owned by the microbes and that it is in our very best interest to know "Who is there?" and "What 
is everybody doing?" Finding the answers to these questions needs an interdisciplinary effort of microbial ecologists, bio(geo) chemists, (eco)physiologists, geneticists, systems microbiologists, biotechnologists, modelers and theoretical biologists. The last decade has, for instance, changed our view on many aspects of the microbial biogeochemical cycles including the already heavily impacted global nitrogen cycle (Rockstrom et al., 2009), which is mainly due to tremendous advances in methods, techniques and approaches. Many novel processes and the molecular inventory and microbes that facilitate them have been discovered only within the last $5-10$ years and the process is in progress. This was also possible because microbiologists came finally to realize that pure culture microbiology - although instrumental for the dissection of cells and the study of how their inner circuits work as well as for the implication of a causal agent in disease - does not reflect how microbes live in their respective environmental niches: Microbes are social beings that live, communicate and work together spatially and temporally embedded in complex communities, be it in water or soil or in facultative or obligate associations with each other or with macroorganismal hosts.

So as we are taking much better account of the unseen majority of life, unravel the biogeochemical processes that microbes facilitate, thereby making planet Earth habitable for all forms of life; as we increasingly identify the rules by which microorganisms interact with co-evolving viruses and "macroorganisms" in health and disease; and as we find more and better strategies to mitigate the detrimental effects of anthropogenic activities on the abundance, diversity, distribution and activity of microbial communities, the grand challenge of Microbiology today is to know better, protect, utilize and celebrate the unseen majority on our planet.

Frontiers in Microbiology with its family of Specialty Journals will be the 21st century approach to communicate all this progress to both the specialist and a wider audience of readers in the field.

\section{ACKNOWLEDGMENTS}

The preparation of this article was in part supported by Incentive Funds provided by the Office of the EVP Research of the University of Louisville and NSF grant MCB0948202. I am grateful for stimulating discussion with Dr. Lisa Y. Stein (University of Alberta-Edmonton, Canada).

\section{REFERENCES}

Behring, E., and Kitasato, S. (1890). Ueber das Zustandekommen der Diphtherie-Immunität und der Tetanus-Immunität bei Thieren. Dtsch. Med. Wochenschr. 16, 1113-1114.

Burrill, T. J. (1878). Pear blight. Trans. Ill. State Hortic. Sci. 11, 114-116.

Ehrlich, P. (1891). Experimentelle Untersuchungen über Immunität, I. Ueber Ricin, II. Ueber Abrin. Dtsch. Med. Wochenschr. Xvii, 976-1218.

Ehrlich, P. (1897). Zur Kenntniss der Antitoxinwirkung. Fortschr. Med. 15, 41-43.

Forterre, P. (2008). In a world of microbes, where should microbiology stand? Res. Microbiol. 159, 74-80.

Glansdorff, N., Xu, Y., and Labedan, B. (2008). The Last Universal Common Ancestor: emergence, constitution and genetic legacy of an elusive forerunner. Biol. Direct 3, 29.

Heijden, M. G. A. v. d., Bardgett, R. D., and Straalen, N. M. v. (2008). The unseen majority: soil microbes as drivers of plant diversity and productivity in terrestrial ecosystems. Ecol. Lett. 11, 296-310.

Ivanowski, D. I. (1892). On two diseases of tobacco. Sel Khoz Lesov 169, 108-121.

Kitasato, S. (1889). Ueber den Tetanusbacillus. Z. Hyg. Infektionskr. 7, 225-234.

Klebs, E. (1883). Ueber Diphtherie. Verhandlungen des Deutschen Kongr. für Innere Mededizin 2, 139-154.

Kluyver, A. J. (1924). Eenheid en verscheidenheid in de stofwisseling der microben. Chem. Weekbl. 21, 266-280.

Kluyver, A. J., and Donker, H. J. L. (1926). Die Einheit in der Biochemie. Chem. Zelle Geweke. 13, 134-190.

Koch, R. (1876). Untersuchungen ueber Bakterien:V.Die Aetiologie der Milzbrand-Krankheit, begruendent auf die Entwicklungsgeschichte des Bacillus Anthracis. Beiträge zur Biologie der Pflanzen 2, 277-310.

Koch, R. (1884). Die Aetiologie der Tuberkulose. Mittheilungen aus dem Kaiserlichen Gesundheitsamt 2, 1-88.

Koonin, E., and Martin, W. (2005). On the origin of genomes and cells within inorganic compartments. Trends Genet. 21, 647-654

Koonin, E. V. (2009). On the origin of cells and viruses. Ann. N. Y. Acad. Sci. 1178, 47-64.

Lane, N., Allen, J. F., and Martin, W. (2010). How did LUCA make a living? Chemiosmosis in the origin of life. Bioessays 32, 271-280.

Lewis, T. R. (1878). The microscopic organisms found in the blood of man and animals and their relation to disease. Ann. Rpt. San. Commis. Govt. India (Calcutta) $14,157$.

Lister, J. (1878). On lactic fermentation and its bearing on pathology. Trans.Path. Soc. (London) xxix, 425-427.

Loeffler, F. (1884). Utersuchung über die Bedeutung der Mikroorganismen für die Entstehung der Diphtherie beim Menschen, bei der Taube und beim Kalb. Mittheilungen aus dem Kaiserlichen Gesundheitsamt. 2, 421-499.
Martin, W., and Russell, M. (2003). On the origins of cells: a hypothesis for the evolutionary transitions from abiotic geochemistry to chemoautotrophic prokaryotes, and from prokaryotes to nucleated cells. Philos. Trans. R. Soc. Lond., B, Biol. Sci. 358, 59-83.

Metschnikoff, I. I. (1884). Ueber eine Sprosspilzkrankheit der Daphnien. Beitrag zur Lehre über den Kampf der Phagocyten gegen Krankheitserreger. Archiv für pathologische Anatomie und Physiologie und für klinische Medizin. 96, 177-195.

Neisser, A. (1879). Ueber eine der Gonorrhoea eigenthümlichen Micrococcusform. Vorlaufige Mitteilung. Cbl.f. d. Med. Wiss. 28, 497-500.

Ophuls, W., and Moffitt, H. C. (1900). A new pathogenic mould. Phila. Med. J. 5, 1471-1472.

Pasteur, L. (1880). Sur les maladies virulentes et en particulier sur la maladie appelee vulgairement cholera des poules. C. R. Acad. Sci. (Paris) 90, 239-248.

Pasteur, L. (1880). De l'attenuation du virus cholera des poules. C. R. Acad. Sci. (Paris) 91, 673-680.

Pasteur, L. (1885). Methode pour prevenir la rage apres morsure. C. R. Acad. Sci. (Paris) 101, 765-773.

Pfeiffer, R. (1894). Weitere Untersuchungen ueber das Wesen der Choleraimmunität und ueber specifisch baktericide Processe. Zeitschrift für Hygiene und Infektionskrankheiten 18, 1-16.

Reed, W., Vaughan, V. C., and Shakespeare, E. O. (1900). Abstract Report on the Origin and Spread of Typhoid Fever in U. S. Military Camps During the Spanish War of 1898. Washington: US Government Printing Office.

Rockstrom, J., Steffen, W., Noone, K., Persson, A., Chapin, F. S., Lambin, E. F., Lenton, T. M., Scheffer, M., Folke, C., Schellnhuber, H. J., Nykvist, B., de Wit, C. A., Hughes, T., van der Leeuw, S., Rodhe, H., Sorlin, S., Snyder, P. K., Costanza, R., Svedin, U., Falkenmark, M., Karlberg, L., Corell, R. W., Fabry, V. J., Hansen, J., Walker, B., Liverman, D., Richardson, K., Crutzen, P., and Foley, J. A. (2009). A safe operating space for humanity. Nature 461, 472-475.

Roux, E., and Yersin, A. (1888). Contribution a l'etude de la diphtherie. Ann. Inst. Pasteur. 2, 629-661.

Russell, M. (2007). The alkaline solution to the emergence of life: energy, entropy and early evolution. Acta Biotheor. 55, 133-179.

Schloesing, J. J. T., and Muntz, A. (1877). Sur la nitrification par les ferments organises. C. R. Acad. Sci. (Paris) LXXXIV, 301-303.

Smith, T., and Kilbourne, F. L. (1893). Investigations into the nature, causation and prevention of Texas or southern cattle fever. Bur. Anim. Ind. Bull. 1, 151-152.

Wachtershauser, G. (1994). Life in a Ligand Sphere. Proc. Natl. Acad. Sci. U.S.A. 91, 4283-4287.

Wachtershauser, G. (2007). On the chemistry end evolution of the pioneer organism (review). Chem. Biodivers. 4, 584-602.

Ward, B. B. (2002). How many species of prokaryotes are there? Proc. Natl. Acad. Sci. U.S.A. 99, 10234-10236.

Welch, W. H., and Nuttall, G. (1892). A gas-producing bacillus (B. aerogenes capsulatus, nov. spec.) capable of rapid development in the blood vessels after death. Bull. Johns Hopkins Hosp. 3, 81-91.

Whitman, W. B., Coleman, D. C., and Wiebe, W. J. (1998). Prokaryotes: the unseen majority. Proc. Natl. Acad. Sci. U.S.A. 95, 6578-6583. 
Winogradsky, S. (1887). Über Schwefelbakterien. Bot. Zeit. XLV, 489-507.

Winogradsky, S. (1890). Recherches sur les organismes de la nitrification. Ann. Inst. Pateur (Paris) 4, 213-231.

Woese, C., and Fox, G. (1977). The phylogenetic structure of the prokaryotic domain: the primary kingdoms. Proc. Natl. Acad. Sci. U.S.A. 74, 5088-5090.

Woese, C., Kandler, O., and Wheelis, M. (1990). Towards a natural system of organisms: proposal for the domains
Archaea, Bacteria, and Eucarya. Proc. Natl. Acad. Sci. U.S.A. 87, 4576-4579.

Wu, R. (1970). Nucleotide sequence analysis of DNA: I. Partial sequence of the cohesive ends of bacteriophage [lambda] and 186 DNA. J. Mol. Biol. 51, 501-521.

Wu, R., and Taylor, E. (1971). Nucleotide sequence analysis of DNA: II. Complete nucleotide sequence of the cohesive ends of bacteriophage [lambda] DNA. J. Mol. Biol. 57, 491-511.

Yersin, A. (1894). La peste bubonique a Hong Kong. Ann. Inst. Pasteur. 8, 662-667.
Received: 11 May 2010; accepted: 12 May 2010; published online: 20 July 2010

Citation: Klotz MG (2010) The grand challenge of microbiology: to know better, protect, utilize and celebrate the unseen majority on our planet. Front. Microbio. 1:1. doi: 10.3389/fmicb.2010.00001

Copyright $(9) 2010$ Klotz. This is an open-access article subject to an exclusivelicense agreement between the authors and the Frontiers Research Foundation, which permits unrestricted use, distribution, and reproduction in any medium, provided the original authors and source are credited. 